\title{
Беларуская гістарыяграфія Вялікага Княства Літоўскага на мяжы XX і XXI ст.: да 25-годдзя кафедры гісторыі Беларусі старажытнага часу і сярэдніх вякоў Беларускага дзяржаўнага ўніверсітэта
}

Вялікае Княства Літоўскае трывала заняло сваё месца ў нацыянальнай гісторы Беларусі. 3'яўляецца ключавой эпохай у разуменні этнаканфесійнага развіцця беларусаў, фарміраванні ментальнасці ва ўмовах цывілізацыйнага і культурнага памежжа, федэратыўным характары дзяржаўнасці ў Сярэднявеччы і раннім Новым часе, канструктах культуры і гістарычнай памяці Беларусі.

Канец 1980-х становіцца адпраўной кропкай для адраджэння даследаванняў Вялікага Княства Літоўскага і як гісторыі Беларусі, і як самастойнай гісторыі рэгіёна Цэнтральнай і Усходняй Еўропы. Сярод якіх палітычная гісторыя і гісторыя эліт займае вядучае месца.

У 1993-1994 гг. ствараецца сучасны нацыянальны гістарычны наратыў Беларусі: прымаецца Канцэпцыя нацыянальнай гісторыі, ствараюцца першыя пост-савецкія падручнікі, уводзіцца спецыяльны прадмет “Гісторыя Беларусі” ў сярэдняй школе і ва ўніверсітэтах (да 1990-х гг. “Гісторыя БССР” выкладалася ў агульным курсе “Гісторыі СССР”). Нацыянальны гістарычны наратыў ува- 
сабляецца не толькі і не столькі ў існаванні адзінага беларускага погляду на гісторыю Вялікага Княства Літоўскага, колькі ў асноўных падыходах і накірунках развіцця даследаванняў. Дэпалітызацыя і нацыянальная арыентаванасць у выкладанні гісторыі Беларусі становяцца пажаданымі. Рэалізацыя канцэпцыі адбывалася ва ўмовах адмаўлення ад “масквацэнтрычнай” гісторыі, якая панавала апошнія паўстагоддзя ў СССР. I назіраецца пераход да “сваёй” гісторыі, якую патрабавалася канструяваць нанова, практычна без вопыту тэкстаў нацыянальнага адраджэння пачатку XX ст., ці спадчыны эпохі беларусізацыі і эмігранцкіх паваенных супольнасцяў.

Беларускі дзяржаўны ўніверсітэт з пачатку 1990-х гг. актыўна ўключыўся ў працу па стварэнню падмурка для сучасных даследаванняў ВКЛ і падрыхтоўцы кадраў у галіне гісторыі Беларусі Сярэднявечча і ранняга Новага часу. Хаця з 1958 г. на гістарычным факультэце ўжо існавала кафедра гісторыі БССР, якая займалася марксісцкай эпохай феадалізму ў Беларусі (пераважна даследаванні вяліся па XVII і XIX ст.). Аднак у 1994 г. было прынята рашэнне пра абнаўленне яе выкладчыцкага складу і пераўтварэнне ў кафедру гісторы Беларусі старажытнага часу і сярэдніх вякоў. Планавалася адкрыць адмысловую спецыялізацыю "Гісторыя Вялікага Княства Літоўскага”. Фарміраваліся агульныя і спецыяльныя курсы для выкладання.

Для рэалізацыі гэтага праекта ў другой палове 1990-х гг. былі запрошаны і спецыялісты па беларускай медыявістыцы. Загадчыкам кафедры стаў Павел Лойка (1958-2010). Ён быў выпускніком гістарычнага факультэта БДУ, сынам вядомага літаратуразнаўцы і паэта Алега Лойкі, колькі год з'яўляўся загадчыкам аддзела ў Інстытуце гісторыі Акадэміі навук. Актыўны даследчык сацыяльна-эканамічных адносін, аўтар дыдактычных тэкстаў па гісторыі Беларусі XVI - XVIII ст. (“Шляхта Вялікага Княства Літоўскага”, “Нарысы гісторы Беларусі”, дапаможнікі па гісторыі Беларусі для сярэдняй школы, метадычная літаратура для настаўнікаў). Такім чынам, Павел Лойка бачыўся тагачаснаму кіраўніцтву гістарычнага факуль- 
Андрэй Любы, Беларуская гістарыяграфія Вялікага Княства Літоўскага. . 423

тэта і асабіста дэкану Пятру Шупляку ідэальным кандыдатам на кіраўніка і трэндмэйкера гісторыі Беларусі эпохі Сярэднявечча і ранняга Новага часу.

Выкладчыцка-прафесарскі склад кафедры, у якім засталося ўсяго некалькі асобаў з папярэдняга часу (Аляксандр Ігнаценка, Уладзімір Сосна, Леанід Жылуновіч), папоўнілі такія спецыялісты ў гісторыі ВКЛ і Рэчы Паспалітай як Уладзімір Емельянчык, Юрый Бохан, Валянцін Голубеў, Юрый Заяц, Любоў Собалева. Большасць з іх навучаліся на гістарычным факультэце, а ў 1990-х з'яўляліся супрацоўнікамі Інстытута гісторыі Акадэміі навук. У 2000-ыя гг. склад кафедры стаў папаўняцца выпускнікамі абноўленай кафедры. Выкладчыкамі сталі Васіль Варонін (спецыяліст па рэгіянальнай гісторыі, сфера яго інтарэсаў палягала ў гісторыі ВКЛ XV-XVI ст.), Алена Дзянісава (паўстанне і развіццё Тураўскай праваслаўнай епархіi). У 2010-ыя гг. да працы на кафедры былі закліканы выпускнікі Кафедры 2000-х гг: Макар Шніп (паўстанне Міхаіла Глінскага), Андрэй Любы (унутрыпалітычны канфлікт у Вялікім Княстве Літоўскім 1430-1440-х гг.), Алена Дземядовіч (знешняя палітыка Рэчы Паспалітай у XVII ст.), Уладзімір Падалінскі (сенатары ВКЛ на Вальных соймах Рэчы Паспалітай), Зміцер Скварчэўскі (астралагічныя веды ў ВКЛ), Сяргей Ганчарэнка (магнатэрыя ВКЛ). А таксама вучаніца Надзеі Высоцкай Вольга Клёцкіна (тэатар Радзівілаў XVIII - пачатак XIX ст.).

За 1994-2019 гг. на кафедральнай спецыяльнасці прайшло навучанне каля паўтары сотні студэнтаў факультэта. Магістратуру па кафедральнай спецыялізацыі скончыла не больш за траціна выпускнікоў. I толькі палова 3 іх працягнулі свае навуковыя даследаванні ў аспірантуры. У XXI ст. на кафедры абарніліся дзесяць дысертацый на саісканне навуковай ступені кандыдата гістарычных навук.

Сярод іх можна вылучыць наступныя накірункі, якія найбольш удала ўпісваліся ў падрыхтоўку спецыялістаў і ўвасобіліся ў персанальныя спецыяльныя курсы. Кожны з накірункаў як ні дзіва развіваўся пад уплывам сваёй метадалогіі. Так палітычная гісторыя, 
гісторыя дзяржаўных інстытутаў, унутрыпалітычныя канфлікты - развіваюцца пад уплывам антрапалагічнага падыходу. Сацыяльная гісторыя пераважна як гісторыя аднаго саслоўяў (складаючымі часткамі якога былі шляхта, магнатэрыя, арыстакратыя, баяры) пад уплывам гістарычнай антрапалогіi і пост-савецкай культуралогіi. Рэгіянальная гісторыя і рэгіянальныя эліты - цывілізацыйны падыход і новае раянаванне (напрыклад, замена дэфініцыі “Усходняя Еўропа" на “Цэнтральная і Усходняя Еўропа").

У новую эпоху развіцця беларускай гістарычнай навукі кафедра гісторыі Беларусі старажытнага часу і сярэдніх вякоў увайшла ў абноўленым ідэйным плане. Калі ў 1950-1980-ыя гг. дамінавала праблематыка старажытнай беларускай культуры і канструяванне вобраза беларускага селяніна ў прасторы Усходняй Еўропы XIII-XVIII ст. То новая плеяда даследчыкаў прапануе новы погляд на гісторыю ВКЛ.

Гэта праявілася ў публікатарскай актыўнасці выкладчыкаў кафедры, якія прынялі актыўны ўдзел у такіх абагульняючых выданнях па гісторыі Беларусі як “Нарысы гісторыі Беларусі” ў 2 частках (1994 і 1996 гг.), “Гісторыі Беларусі” ў 6-ці тамах (Т. 2: Беларусь у перыяд Вялікага Княства Літоўскага; Т.3. Беларусь у Рэчы Паспалітай). Але перадусім увасобілася ў стварэнні новых курсаў, якія пашыралі праблемнае поле, стваралі падмурак для новай генерацыі даследчыкаў. Так з сімбіёзу навучальных курсаў і персанальных даследаванняў з'яўляюцца праблемныя кластэры ваеннай гісторыі Вялікага Княства Літоўскага (Юрый Бохан), аналіз крызіса і рэформаў Рэчы Паспалітай XVIII ст. (Уладзімір Емельянчык), метадалогія гістарычнага даследавання і традыцыі ў гістарыяграфіі (Генадзь Сагановіч), рэгіянальная гісторыя (Юрый Заяц, Васіль Варонін).

Вынік падобнай працы мы можам пабачыць у другой палове 1990-х - першай палове 2000-х гг. - гэта час абарон кандыдацкіх дысертацый новага пакалення даследчыкаў ВКЛ, цалкам сфарміраванага пад уплывам выкладчыкаў-даследчыкаў 1990-х гг.

Даследаванні шляхты беларускіх зямель XVI-XVII ст. Паўла Лойкі зрабілі ўмовы для даследаванняу сацыяльна-палітычнай 
Андрэй Любы, Беларуская гістарыяграфія Вялікага Княства Літоўскага. . 425

гісторыі Вялікага Княства Літоўскага, а з часам і афармлення ў сценах гістарычнага факультэта персанальнай навуковай школы. Даследаванні магнатэрыі, інстытутаў дзяржаўных ураднікаў, пахавальнай культуры шляхты, сарматызму пашырылі ўласна працы П. Лойкі. Які заўчасна пасля доўгай хваробы сышоў з жыцця ў восені 2010 г.

32010 г. Кафедра распачынае шэраг спецыялізаваных навуковых мерапрыемстваў па гісторыі Вялікага Княства Літоўскага, аналагаў якім няма ні ў Інстытуце гісторыі, ні ў іншых навучальных установах Беларусі. Мерапрыемствы былі прымеркаваны: да 600-годдзя перамогі пад Грунвальдам; 1150-годдзю г. Полацка і гісторыі Полацкай зямлі IX-XVIII ст. (2012 г.); “Хрысціянскія традыцыі сярэднявечнай Беларусі (да 1025-годдзя хрысціянізацыі Русі)” (2013 г.); “Айчынная гістарыяграфія на мяжы XX і XXI ст.: прысвечаны 20-годдзю кафедры гісторыі Беларусі старажытнага часу і сярэдніх вякоў” і “Актуальныя пытанні ваеннай гісторыі Сярэднявечча і ранняга Новага часу : да 500-годдзя Аршанскай бітвы” (у 2014 г.); "Соцыум Вялікага Княства Літоўскага: уладная, прававая, эканамічная стартыфікацыя Беларусі XV-XVIII ст.” (2015 г.); “Асоба і Гісторыя (да 100-годдзя з дня нараджэння Л.С. Абэцэдарскага)” (2016 г.); “Сацыяльна-эканамічнае вымярэнне Беларусі (да Юбілеяў М.В. Доўнар-Запольскага і А.П. Ігнаценкі)” (2017г.); у 2018 г. праведзены круглы стол “Ад урбаністыкі да ўзбраення Вялікага Княства: памяці доктара гістарычных навук Юрыя Мікалаевіча Бохана”. У 2018 і 2019 гг. праведзены дзве міжнародныя канферэнцы па гісторыі Вялікага Княства Літоўскага, прымеркаваныя двум юбілеям - 60-годдзю $з$ дня нараджэння П.А. Лойкі і чвэрці стагоддзя існавання Кафедры ў новым фармаце.

У канцы 2000-х пачынаецца інтэнсіўная праца над пераасэнсаваннем нацыянальнага наратыва. Калі ў 1990-ыя гг. ва ўмовах будовы нацыянальнай дзяржавы традыцыя наратыва дыктавала вывучэнне пераважна “сябе”, то ў 2000-ыя наратыў адпавядаў фармату “ў кантэксце цывілізацыі”. Як ні дзіўна гэта тэндэнцыя павінна была 
запатрабаваць вывучэнне буйных праблем з гісторыі шматэтнічнай і полірэлігійнай дзяржавы Вялікае Княства Літоўскае, прыход новай метадалогіi... Але адбываецца адваротны працэс - паступова праблематыка Вялікага Княства ў нацыянальным гістарычным наратыве Беларусі выхалашчваецца, дэвальвуецца і праходзіць стады сегментацыі. Напачатку 2010-х гг. беларуская гістарыяграфія сутыкаецца 3 сітуацыяй разрыва паміж зместам абагульняючых прац, дыдактычнай літаратуры і навацыямі ў даследаваннях эпохі, якія праводзяць асобныя даследчыкі.

Так першую палову 2010-х для ўсёй беларускай медыявістыкі можна ахарактарызаваць як перыяд запаволенасці ў даследаваннях Вялікага Княтсва Літоўскага і незапатрабаванасці іх пры напісанні абагульняючых прац. Хаця менавіта ў гэты час ажыўляецца працэс абароны доктарскіх дысертацый па эпохе Вялікага Княства Літоўскага (Валянцін Голубеў, Сяргей Стрэнькоўскі, Андрэй Мяцельскі). Аднак адбываецца гэта па-за ўніверсітэтам.

У чым прычыны крызісу гісторыі Вялікага Княства Літоўскага на сучасным этапе развіцця беларускай гістарыяграфіi? Верагодна, гэта моцна звязана з сыходам $з$ жыцця ці актыўнай навуковай дзейнасці аўтарытэтаў 1980-1990-х (У. Емельянчыка, Ю. Зайца, П. Лойкі, Ю. Бохана, М. Спірыдонава), а таксама сыход прадстаўнікоў і наступнага пакалення 2000-х (такіх асоб як Віктар Цемушаў і Міхаіл Папоў). Пры ўсёй колькасці выпускнікоў аспірантуры па спецыяльнасці “айчынная гісторыя” ў Беларусі не хапіла кампенсаторнай моцы на ўзнаўленне патэнцыялу (прычым як саміх даследчыкаў, так і навуковых кіраўнікоў).

Аднак, на Кафедры уужо пяць год дзейнічае навуковы семінар А. Любага "Seminarium: Прастора ВКЛ”, які дае магчымасць часцей сустракацца ўжывую спецыялістам з розных навучальных і навуковых установаў Беларусі і замежных навуковых інстытутаў (Літвы, Польшчы, Украіны). І такім чынам уключаць студэнтаў, магістрантаў і маладых навуковых спецыялістаў у адзіную нешматлікую супольнасць даследчыкаў Вялікага Княства Літоўскага. 